\title{
WOMEN PARTICIPATION IN TOURISM DEVELOPMENT IN NIGERIA: AN X-RAY OF THE PLACE OF WOMEN IN AN EMERGING INDUSTRY
}

\author{
Dr. Olumuyiwa A. Akande \\ Centre for Sustainable Development, \\ Faculty of Multidisciplinary Studies, \\ University of Ibadan, Ibadan, Nigeria \\ Dr. Temitope Francis Abiodun \\ Department of Peace, Security and Humanitarian Studies, \\ Faculty of Multidisciplinary Studies, \\ University of Ibadan, Nigeria \\ Kemi Opeyemi John \\ Graduate Student, Centre for Sustainable Development, \\ Faculty of Multidisciplinary Studies, \\ University of Ibadan, Ibadan, Nigeria
}

\begin{abstract}
The tourism experience was perceived traditionally, in terms of products, destinations and consumption patterns. Women have contributed greatly to tourism development, promoting transport development and encouraging hotel progress, which help in reducing or eliminating poverty. This study sheds light on the extent of women participation in tourism development. The specific objective of the study is to examine the factors affecting women participation in tourism development and how tourism industry benefits women. This study collected qualitative and quantitative data from respondents; primary and secondary sources. Data were collected using two methods: oral interview and administration of structured questionnaires, which were randomly administered at the various study sites. The data were analyzed by using descriptive statistic, simple percentages, bar-chart, pie-chart and chi-square respectively. Results obtained revealed that $90.8 \%$ of the factors affecting women participation in tourism development include: lack of financial capital, poverty, illiteracy, traditional perception, religious factor, child bearing and career development issues. The findings also indicated that $88 \%$ of the respondents are of the opinion that policies such as tourism education, trainings, internet marketing, and formation of business network for self-support and municipality support can be employed to improve women participation in tourism development. The study therefore recommended that there should be training programmes, workshops and seminars financed by Oyo State Government to improve the business skills of women in tourism, hotel and transportation industry, among others.
\end{abstract}

Keywords: Women Participation, Employment Status, Economic Benefits, Traditional Perception, Equal Benefits, Tourism Development 


\section{Introduction}

Tourism is not only ideally poised to ensure prosperity, but also to promote empowerment, gender equality, youth employment and children's inclusion. Women have considerable potentials and experience of managing tourism component such as accommodation, transportation and conserving natural attraction resources (UNWTO, 2017). Till date, the tourism sector has played a significant role in empowering women politically, socially and economically. However, decisive action on behalf of both men and women's employment are ending all forms of discrimination. Worldwide, women organizations have contributed greatly to achieving sustainable development, promoting and encouraging progress of women working in tourism sectors, hotel industry and transport sector which will help reduce or eliminate poverty (WTO, 2016).

According to United Nation World Tourism Organization, tourism is a rapidly growing phenomenon and has become one of the largest and fastest growing industries in the World (UWTO, 2017). At the national level, it generates revenues and acts as an engine for development through Foreign exchange earnings at local levels. It also creates direct and indirect employment and distributes income to local people (Davies, 2015).The contribution of tourist to Nigeria's Gross Domestic Product (GDP) from government revenues generated via levies on the hospitality sector is put at \#1.149million in 2017, while in (2018) total revenue of \#3133.00 billion was generated from oil and tourisms which dominates the economy in areas of construction, telecommunications retail and manufacturing (Ayeni, 2013).

Women do get involved or employed but the level of involvement is low and relatively insignificant as most are employed in the low-skilled sector of the industry such as housekeeping vendor, cleaners cook assistants, and waitressing. The reason for this situation include wide spread of poverty, illiteracy and lower access to land capital than their male counterpart. Women are well represented in service and clerical levels jobs but poorly represented at professional levels. Women occupy fewer than $30 \%$ of all post in public sector and only $17 \%$ of this in senior Cadre. Only one in every three employees in tourism sector is a woman due to inadequate access to financial resource, lack of education, training and inadequate motivation.

Based on the above problems, the objectives of the study are: to examine the extent of women participation in tourism sector, accommodation and transportation industry; to examine the roles and employment status of women's in the tourism sector; to examine how tourism sector benefits women; to examine the factors affecting the participation of women in tourism development; and to examine the policy and efforts put in place to encourage women participation in tourism development.

\section{Conceptual Framework}

Women Participation

The following diagram indicates the role of women participation in basic element of tourism. As a services based industry, tourism consists of a number of tangible and intangible elements include basic infrastructure such as transport, accommodation, tours, souvenirs while the intangible element or components the education, culture, adventure or simply escape and relaxation. 


\section{BASIC ELEMENTS OF TOURISM}

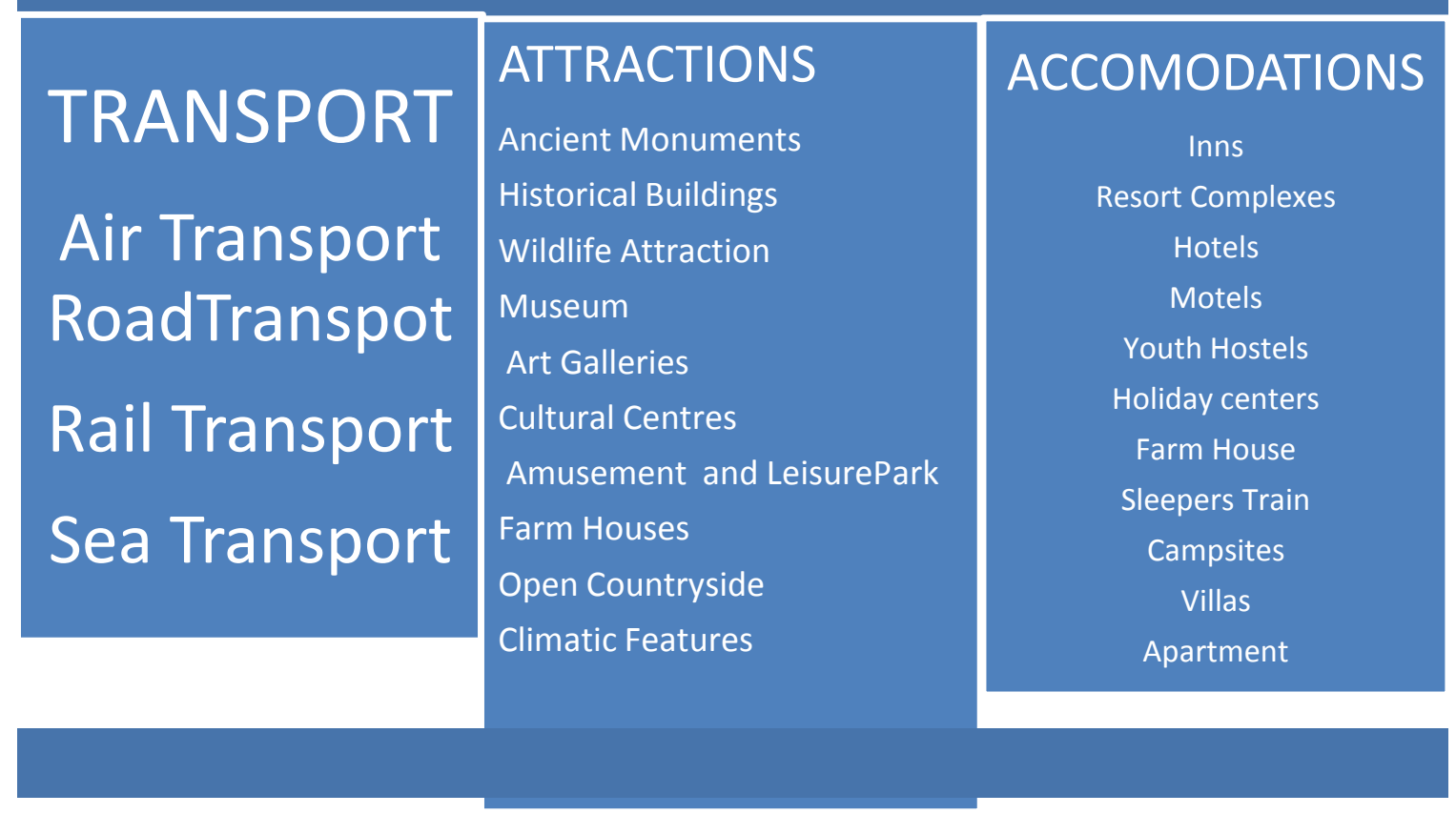

Source: (Bhatia, A. 2017).

Ateljeuic \& Peter (2017) stated that women became important after being acknowledged by United Nation's Millenniums Development Goal (MDG) in which five out of eight goal are directly and indirectly related to women empowerment "promote gender equality", which aims are to benefit poor through tourism, protect the environment and empower women.

Tourism creates important employment opportunities to women and in most of the case income generated either as the main source of income. ILO estimates women account for $46 \%$ of wage employment in tourism globally and up to $90 \%$ if including catering, transportation and accommodation sector (DM Cross Cutting Issues and Gender, 2012). It is important to identify that tourism jobs are often flexible and can be done from the work place, households or communities. As employees, women are well represented in tourism destination, but they are more likely to reach tourism professional employment level. Generally, their average income is lower than men's. The working conditions for unskilled women are mostly sub-standard. 


\section{Theoretical Framework}

This study is based on the combine theories of Participation and Empowerment.
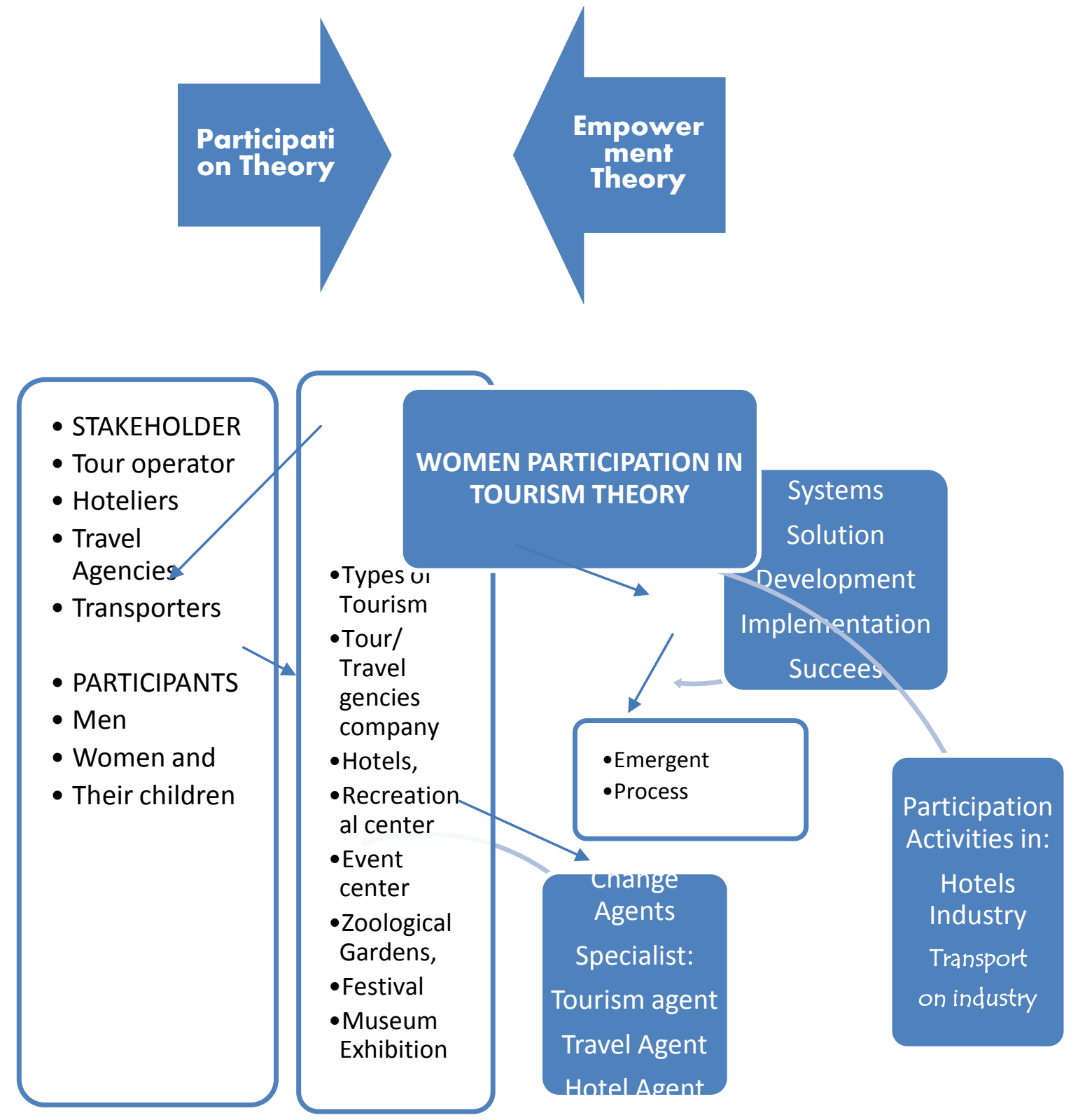

Source: (Markus and Mao, 2018)

\section{Participation Theory}

According to Jorge F, (2018), participation theory is a conceptual framework which attempts to bridge the subject and object distinction. It is a theory of knowledge which holds that meanings are enacted through the participation of women mind and power with tourism. Claridge (2004) in his Report "Designing Social Capital Sensitive Participation Methodologies" observed that the importance of participation grew out of the recognition that the worlds' poor have actually suffered as a result of development, and that everyone including women needs to be involved in tourism development, decision making, 
implementation, transportation sector, accommodation, and tourist destination/attraction benefits.

Women participation refers to collective or individual processes which influences decision making process in the tourism organization. The aim of optimizing participation and engagement of women in tourism provides an opportunity to design tools informed by the updated participatory information systems theory in application to women. Participation theory is a theory of knowledge which holds that meaning is enacted through the participation of women mind. Equal participation in society whether in terms of opportunities or outcomes requires effort in legal, social, political and cultural domains to tackle all forms of women discrimination.

\section{Empowerment Theory}

Empowerment is the granting of political, social or economic power to an individual. It refers to as women engagement in informal and formal capacities. Empowerment is both a value orientation for working in the community and theoretical model for understanding the process and consequences of efforts to exert control and influence over decisions that affect one's life, organizational functioning and the quality of community life (Perkins\& Zimmerman, 1995 \& Warschausky, 1998). The value orientation of empowerment suggests goals, aims and strategies for implementing change. Empowerment theory provides principles and a framework for organizing women knowledge. The development of empowerment theory also helps to advance the construct beyond a passing political manipulation.

\section{Methodology}

The work evaluates tourism centres within Ibadan Metropolis in Oyo State from year (20132018) while the population for this study was made up of some specific people who are more knowledgeable on the tourism values, hotel and transport sector. The study employed both the primary and secondary sources for data gathering. Two hundred and (220) copies of the questionnaire were administered by the researcher while a total of 180 questionnaires were retrieved. Also, the secondary data were gathered through interaction with different publications that are relevant on the subject matter and related discipline while the results were content analyzed. 
Journal DOI: www.doi.org/10.46654/IJRESD

Article DOI: www.doi.org/10.46654/IJRESD.1327

Findings and Discussions

Table 1: Groups of Respondents

\begin{tabular}{|l|l|l|l|}
\hline $\begin{array}{l}\text { S/ } \\
\text { Group }\end{array}$ & Frequency & Percentage \% \\
\hline 1 & UI Zoological Garden & 20 & 11.1 \\
\hline 2 & Agodi Garden & 20 & 11.1 \\
\hline 3 & National Museum Unity & 20 & 11.1 \\
\hline 4 & Trans Amusement Park & 20 & 11.1 \\
\hline 5 & $\begin{array}{l}\text { 5 Hotels in Ibadan Metropolis } \\
\text { Company Peace Mass Transit Transport }\end{array}$ & 30 & 16.6 \\
\hline 6 & $\begin{array}{l}\text { Company } \\
\text { Company }\end{array}$ & 30 & 16.6 \\
\hline 8 & Oyo State Tourism Board Travel Agencies & 10 & 16.6 \\
\hline & TOTAL & 180 & 5.6 \\
\hline
\end{tabular}

Source: (Field Survey, 2019)

\section{Figure 4.1: Group of Respondents}

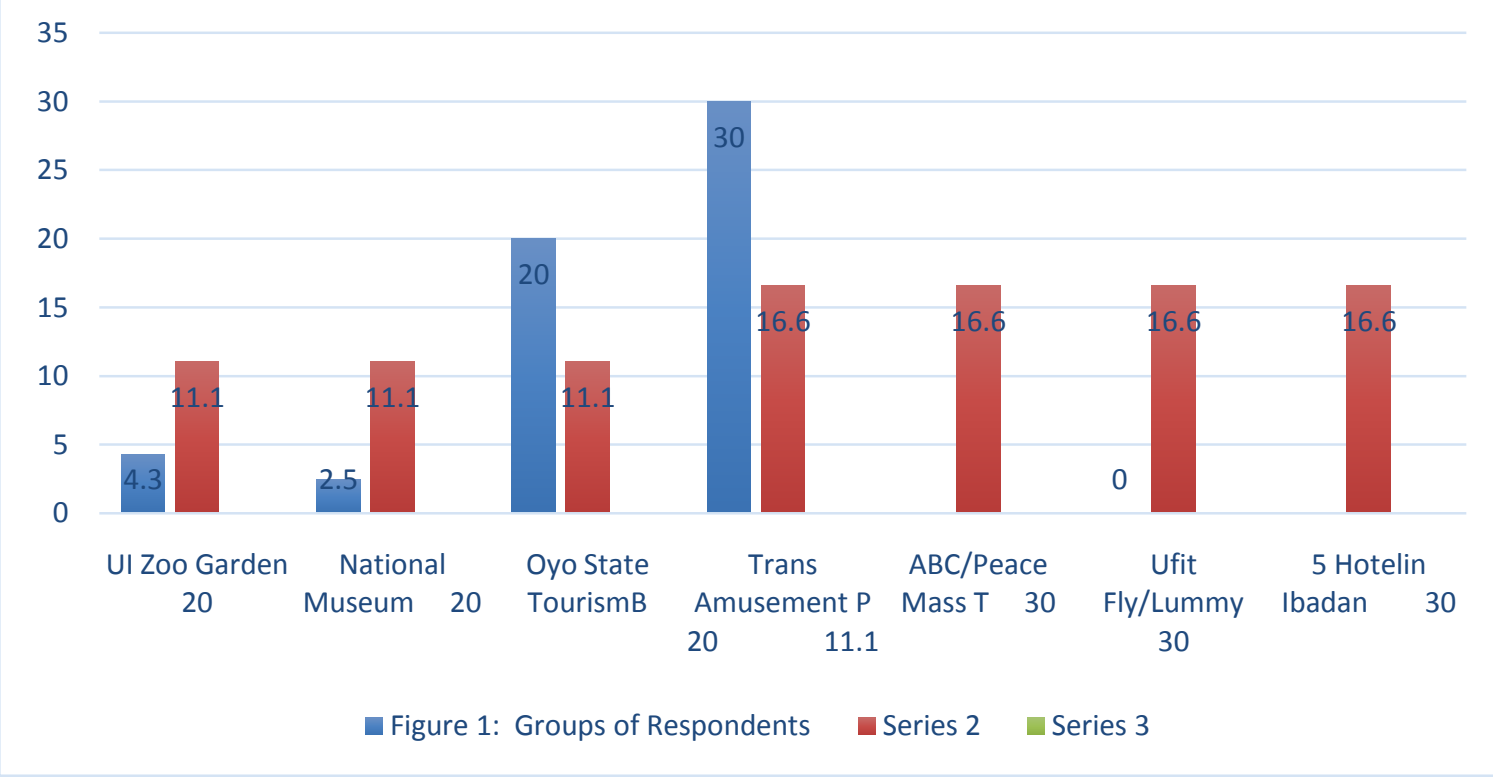


A total number of one-hundred and eighty respondents were interviewed. 20(11.1\%) were interviewed from UI Zoological Gardens, Agodi Gardens, Trans Amusement Park and National Museum of Unity while 30(16.6\%) where interviewed from, ABC/ Peace Mass Transit Transport Company, Ufitfly/Lummy Travel Agencies Company and 5 Hotels in Ibadan Metropolis, 10 (5.5\%) were from Oyo State Tourism Board.

\section{DESCRIPTIVE ANALYSIS OF SOCIO-DEMOGRAPHIC CHARACTERISTICS OF RESPONDENTS}

\begin{tabular}{|l|l|l|}
\hline DEMOGRAPHC & FREQUENCY & PERCENTAGE \\
\hline Sex & & \\
Male & 79 & 43.9 \\
Female & 101 & 56.1 \\
Total & $\mathbf{1 8 0}$ & $\mathbf{1 0 0 . 0}$ \\
\hline Age & & \\
$11-20$ & 40 & 22.2 \\
$21-30$ & 51 & 28.3 \\
$31-40$ & 46 & 25.6 \\
$41-50$ & 34 & 18.9 \\
>=51 & 9 & 5.0 \\
Total & $\mathbf{1 8 0}$ & $\mathbf{1 0 0}$ \\
\hline Religion & 130 & \\
Christianity & 46 & 25.2 \\
Islam & 4 & 2.2 \\
Traditional & $\mathbf{1 8 0}$ & $\mathbf{1 0 0}$ \\
Total & 91 & \\
\hline Marital Status & 82 & 50.6 \\
Married & 7 & 45.6 \\
Single & $\mathbf{1 8 0}$ & 3.9 \\
Widowed & & $\mathbf{1 0 0}$ \\
Total & & \\
\hline Educational & \\
Qualification & Secondary School & \\
\hline
\end{tabular}




\begin{tabular}{|c|c|c|}
\hline $\begin{array}{l}\text { NCE /OND } \\
\text { HND/ BSC } \\
\text { Higher Degree } \\
\text { NONE } \\
\text { Total }\end{array}$ & $\begin{array}{l}40 \\
68 \\
35 \\
\\
180\end{array}$ & \begin{tabular}{|l}
22.2 \\
37.8 \\
19.4 \\
\\
$\mathbf{1 0 0}$
\end{tabular} \\
\hline $\begin{array}{l}\text { Occupation } \\
\text { Student } \\
\text { Civil servant } \\
\text { Self- employed } \\
\text { Travel agencies } \\
\text { Transporter } \\
\text { Hoteliers } \\
\text { Total }\end{array}$ & $\begin{array}{l}32 \\
25 \\
33 \\
30 \\
30 \\
30 \\
\\
180\end{array}$ & $\begin{array}{l}17.8 \\
13.9 \\
18.3 \\
16.7 \\
16.7 \\
16.7 \\
\\
100\end{array}$ \\
\hline Monthly Income & & \\
\hline $\begin{array}{l}\leq=\# 20,000 \\
\# 20,000-\quad \# 40,000 \\
\# 40,001-\# 60,000 \\
61,001-\# 80,000 \\
\geq \# 80,000 \\
\text { Total }\end{array}$ & $\begin{array}{l}69 \\
43 \\
22 \\
15 \\
28 \\
3 \\
\mathbf{1 8 0}\end{array}$ & $\begin{array}{l}38.3 \\
23.9 \\
12.2 \\
8.3 \\
15.6 \\
1.7 \\
\mathbf{1 0 0}\end{array}$ \\
\hline
\end{tabular}

Source: Field Work, 2019

\section{OBJECTIVE ONE (1): THE EXTENT OF WOMEN PARTICIPATION IN TOURISM DEVELOPMENT.}

\section{Findings and Results}

Results show that $44 \%$ of the respondents strongly agreed and $34.4 \%$ agreed that tourism is a male dominated sector. $2.7 \%$ were neutral. Just $11.1 \%$ strongly disagreed and $7.2 \%$ disagreed to the claim.

Results show that $31.0 \%$ of the respondents strongly agreed and $40 \%$ agreed that women participation in tourism sector is low. Similarly, $2.7 \%$ of the respondents strongly disagree and $2.8 \%$ of the respondents disagree to the claim. Just $1.6 \%$ showed neutral opinion. 
Results show that $52.1 \%$ of the respondents strongly agreed and $41.1 \%$ agreed that the extent of women participation in accommodation sector is high. Similarly, $15 \%$ strongly disagree and $9 \%$ disagreed with the claim. $1.1 \%$ of the respondents' opinions were neutral.

Results show that $48 \%$ of the respondents strongly agreed and $33.3 \%$ agreed that Women are better at marketing accommodation facilities. Only $7.2 \%$ strongly disagreed and $6.6 \%$ disagreed with the claim. $6 \%$ of the respondents' opinions were neutral.

Results show that $40 \%$ of the respondents strongly agreed and $35 \%$ agreed that few women participate in transportation sector. Only $15 \%$ strongly disagreed and $8.8 \%$ disagreed with the claim. $1.1 \%$ of the respondents' opinions were neutral.

Results show that $52.2 \%$ of the respondent strongly agreed and $39.4 \%$ agreed that Women are better at marketing Tourism Product. Only $4.4 \%$ strongly disagreed and $2.2 \%$ disagreed with the claim. $1.6 \%$ of the respondents' opinions were neutral.

Results show that $34.4 \%$ of the respondent strongly agreed and $31.1 \%$ agreed that Women are better resources for International Tourism Development. Only 25\% strongly disagreed and $9.4 \%$ disagreed with the claim. $2.7 \%$ of the respondents' opinions were neutral.

Results show that $45 \%$ of the respondents strongly agreed and $36.6 \%$ agreed that Women are key in promoting cultural tourism. Only $10 \%$ disagreed and $6.1 \%$ strongly disagreed with the claim. $2.2 \%$ of the respondents' opinions were neutral.

Results show that $43.3 \%$ of the respondents strongly agreed and $35.5 \%$ agreed that Women are Men participate in festival affairs than women. Only $11.1 \%$ disagreed and $7.2 \%$ strongly disagreed with the claim. $2.7 \%$ of the respondents' opinions were neutral.

Results show that $50 \%$ of the respondents strongly agreed and $44.4 \%$ agreed that Zoological garden, Agodi Garden and other recreational centers, are part of tourism attraction in Oyo State. Only $2.2 \%$ disagree and $2.2 \%$ strongly disagreed with the claim. $1.1 \%$ of the respondents' opinions were neutral.

Conclusion: Women participate in tourism industry.

\section{OBJECTIVE TWO (2): THE ROLE AND EMPLOYMENT STATUS OF WOMEN'S IN TOURISM SECTOR}

Results show that $39.4 \%$ of the respondents strongly agreed and $36.6 \%$ agreed that Tourism sectors offered empowerment to women. Only $13.3 \%$ disagreed and $6.7 \%$ strongly disagreed with the claim. $3.8 \%$ of the respondents' opinions were neutral.

Results show that $45.5 \%$ of the respondents Agreed and $45.5 \%$ strongly agreed that Tourism sector empowers women politically, socially, and economically. Only $11.1 \%$ disagreed and $8.8 \%$ strongly disagreed with the claim. $1.1 \%$ of the respondents' opinions were neutral.

Results show that $40 \%$ of the respondents strongly agreed and $28.3 \%$ agreed that Employment status of women in tourism sector is low. Only $16.7 \%$ disagreed and $12.8 \%$ strongly disagreed with the claim. $1.7 \%$ of the respondents' opinions were neutral. 
Results show that $50 \%$ of the respondents strongly agreed and $44.4 \%$ agreed that Travel Agents play important Roles in Tourism Development. Only 2.2\% disagreed and 1.1\% strongly disagreed with the claim. $1.1 \%$ of the respondents' opinions were neutral.

Results show that $50 \%$ of the respondents strongly agreed and $43.9 \%$ agreed that Tour Agents play important roles in Tourism Development. Only 3.3\% disagreed and 1.7\% strongly disagreed with the claim. $1.1 \%$ of the respondents' opinions were neutral.

Results show that $52.2 \%$ of the respondent strongly agreed and $38.8 \%$ agreed that Employment status of women in accommodation industry is high. Only $4.4 \%$ disagree and $3.3 \%$ strongly disagreed with the claim. $2.2 \%$ of the respondents' opinions were neutral.

Results show that $48.3 \%$ of the respondents strongly agreed and $40 \%$ agreed that the role of women as a receptionist in the hotel industry is important. Only $4.4 \%$ strongly disagreed and $3.8 \%$ disagree with the claim. $3.3 \%$ of the respondents' opinions were neutral.

Results show that $43.3 \%$ of the respondents strongly agreed and $44.4 \%$ agreed that Employment status of women in Transport Industry is low. Only 5.6\% strongly disagreed and $5.0 \%$ disagreed with the claim. $1.7 \%$ of the respondents' opinions were neutral.

Results show that $46.1 \%$ of the respondents strongly agreed and $41.6 \%$ agreed that Women participation in recreational center, Trans-Amusement Park, and others tourist destinations is important. Only $5.0 \%$ strongly disagreed and $4.4 \%$ disagreed with the claim. $2.7 \%$ of the respondents' opinions were neutral.

Results show that $42.2 \%$ of the respondent strongly agreed and $42.8 \%$ agreed that Women are the key in organizing tourist attraction. Only 8\% strongly disagreed and 7\% disagreed with the claim. $3.3 \%$ of the respondents' opinions were neutral.

Conclusion: Women are offered employment in tourism but do not play key roles.

\section{OBJECTIVE THREE (3): HOW TOURISM SECTOR BENEFITS WOMEN}

Results show that $51.1 \%$ of the respondents strongly agreed and $38.8 \%$ agreed that Tourism is a major source of income generation for women. Only 3.9\% strongly disagreed and 3.3\% strongly disagreed with the claim. $2.8 \%$ of the respondents' opinions were neutral.

Results show that $43.3 \%$ of the respondent strongly agreed and $33.8 \%$ agreed that Tourism sector benefits women through entrepreneurship. Only $9.4 \%$ strongly disagreed and $8.3 \%$ disagreed with the claim. $4.4 \%$ of the respondents' opinions were neutral.

Results show that $45 \%$ of the respondents strongly agreed and $34.4 \%$ agreed that Employment status of women in tourism sector is low. Only $10 \%$ strongly disagree and $8.9 \%$ disagreed with the claim. $1.7 \%$ of the respondents' opinions were neutral.

Results show that $42.2 \%$ of the respondents strongly agreed and $41.1 \%$ agreed that the Hotel sector is a major source of income for women. Only $3.9 \%$ strongly disagreed and $3.3 \%$ disagreed with the claim. $2.8 \%$ of the respondents' opinions were neutral.

Results show that $33.3 \%$ of the respondents strongly agreed and 30.5\% agreed that Women benefit from accommodation industry. Only $17.8 \%$ strongly disagreed and $16.1 \%$ disagreed with the claim. $2.2 \%$ of the respondents' opinions were neutral. 
Results show that $16.7 \%$ of the respondents strongly agreed and $16.7 \%$ agreed that Transportation sector is a major source of income generation for women. Only $39.4 \%$ strongly disagreed and $22.2 \%$ disagreed with the claim. $5 \%$ of the respondents' opinions were neutral.

Results show that $45 \%$ of the respondents strongly agreed and $38.9 \%$ agreed that few women benefit from transportation sector. Only 35\% strongly disagreed and 9.4\% disagreed with the claim. $1.1 \%$ of the respondents' opinions were neutral.

Results show that $42.8 \%$ of the respondent strongly agreed and $40 \%$ agreed that Transportation services offer flexible work arrangements for women. Similarly $5.6 \%$ strongly disagreed and $4.4 \%$ disagreed with the claim. $1.7 \%$ of the respondents' opinions were neutral.

Results show that $46.7 \%$ of the respondents strongly agreed and $39.4 \%$ agreed that several women generate income from cultural tourism and recreational centres. Similarly $6.1 \%$ strongly disagreed and $4.4 \%$ disagreed with the claim. $3.3 \%$ of the respondents' opinions were neutral.

Results show that $46.7 \%$ of the respondents strongly agreed and $39.4 \%$ agreed that several women generate income from cultural tourism and recreational centres. Similarly $6.1 \%$ strongly disagreed and $4.4 \%$ disagreed with the claim. $3.3 \%$ of the respondents' opinions were neutral.

Results show that $49.4 \%$ of the respondents strongly agreed and $44.4 \%$ agreed that Women participate in Festival as spectator. Similarly $2.8 \%$ strongly disagreed and $2.2 \%$ disagreed with the claim. $1.1 \%$ of the respondents' opinions were neutral.

Conclusion: Tourism sector benefits women.

\section{OBJECTIVE FOUR (4): FACTORS AFFECTING THE PARTICIPATION OF WOMEN IN TOURISM DEVELOPMENT}

Results show that $47.8 \%$ of the respondents strongly agreed and $45.6 \%$ agreed that Illiteracy is one of the factors affecting women participation in tourism industry. Similarly $3.8 \%$ strongly disagreed and $2.8 \%$ disagreed with the claim. $1.1 \%$ of the respondents' opinions were neutral.

Results show that $50 \%$ of the respondents strongly agreed and $40 \%$ agreed that Poverty is affecting women participation in tourism development. Similarly $3.9 \%$ strongly disagreed and $3.3 \%$ disagreed with the claim. $2.8 \%$ of the respondents' opinions were neutral.

Results show that $38.9 \%$ of the respondents strongly agreed and $30.5 \%$ agreed that Women are negatively affected when they are prevented from reaching managerial positions. Similarly $13.9 \%$ strongly disagreed and $12.9 \%$ disagreed with the claim. $3.9 \%$ of the respondents' opinions were neutral.

Results show that $44.4 \%$ of the respondents strongly agreed and $43.3 \%$ agreed that Child bearing and career development are affecting women participation in tourism. Similarly $5.0 \%$ strongly disagreed and $5.0 \%$ disagreed with the claim. $2.2 \%$ of the respondents' opinions were neutral. 
Results show that $48.9 \%$ of the respondents strongly agreed and $33.3 \%$ agreed that limited participation of women in transportation industry could be seen is as gender- bias. Similarly $8.3 \%$ strongly disagreed and $6.7 \%$ disagreed with the claim. $2.7 \%$ of the respondents' opinions were neutral.

Results show that $41.7 \%$ of the respondents strongly agreed and $40.5 \%$ agreed that Women in transportation industry are not adequately engaged. Similarly $9.4 \%$ strongly disagreed and $5.6 \%$ disagreed with the claim. $2.7 \%$ of the respondents' opinions were neutral.

Results show that $44.4 \%$ of the respondents strongly agreed and $37.2 \%$ agreed that Women are economically affected when they are excluded from transportation services. Similarly $8.9 \%$ strongly disagreed and $6.1 \%$ disagreed with the claim. $3.3 \%$ of the respondents' opinions were neutral.

Results show that $46.7 \%$ of the respondents strongly agreed and $38.9 \%$ agreed that Women who work in the accommodation sector are not adequately remunerated

Similarly $6.7 \%$ strongly disagreed and $5.6 \%$ disagreed with the claim. $2.2 \%$ of the respondents' opinions were neutral.

Results show that $43.3 \%$ of the respondents strongly agreed and $36.6 \%$ agreed that inadequate financial resources hinder women from investing in hotel industry

Similarly $11.1 \%$ strongly disagreed and $6.1 \%$ disagreed with the claim. $2.7 \%$ of the respondents' opinions were neutral.

Results show that $53.8 \%$ of the respondents strongly agreed and $41.6 \%$ agreed that Sexual issues, religion, cultural, and biological factors affect women participation in tourism. Similarly $2.7 \%$ strongly disagreed and $1.1 \%$ disagreed with the claim. $0.5 \%$ of the respondents' opinions were neutral.

Conclusion: There are factors affecting the participation of women in tourism development.

\section{OBJECTIVE FIVE (5): POLICIES AND EFFORTS PUT IN PLACE TO ENCOURAGE WOMEN PARTICIPATION IN TOURISM DEVELOPMENT}

Results show that $50.5 \%$ of the respondents strongly agreed and $38.9 \%$ agreed that Tourism education is one of the policies to improve women participation. Similarly $5.0 \%$ strongly disagreed and $3.9 \%$ disagreed with the claim. $1.7 \%$ of the respondents' opinions were neutral.

Results show that $44.4 \%$ of the respondents strongly agreed and $43.3 \%$ agreed that Training women will improve their participation in tourism. Similarly $5.0 \%$ strongly disagreed and $5.6 \%$ disagreed with the claim. $2.2 \%$ of the respondents' opinions were neutral.

Results show that $42.8 \%$ of the respondents strongly agreed and $43.9 \%$ agreed that Women work as policy- makers in tourism destination sector. Similarly $3.3 \%$ strongly disagreed and $7.2 \%$ disagreed with the claim. $2.8 \%$ of the respondents' opinions were neutral.

Results show that $37.2 \%$ of the respondents strongly agreed and $37.8 \%$ agreed that Women work as policy -makers in accommodation sector. Similarly $11.1 \%$ strongly disagreed and $9.4 \%$ disagreed with the claim. $4.4 \%$ of the respondents' opinions were neutral. 
Results show that $53.3 \%$ of the respondents strongly agreed and $38.9 \%$ agreed that Hotel management education is one of the policies to improve women participation. Similarly $4.4 \%$ strongly disagreed and 3.3\% disagreed with the claim. 3.3\% of the respondents' opinions were neutral.

Results show that $35.6 \%$ of the respondents strongly agreed and $46.1 \%$ agreed that Government made important efforts to improve women participation in tourism development. Similarly $9.4 \%$ strongly disagreed and $7.8 \%$ disagreed with the claim. $1.1 \%$ of the respondents' opinions were neutral.

Results show that $38.3 \%$ of the respondents strongly disagreed and $27.8 \%$ disagreed that Women work as policy maker in transportation sector. Similarly $12.8 \%$ strongly agreed and $15 \%$ agreed with the claim. $6.1 \%$ of the respondents' opinions were neutral.

Results show that $41.1 \%$ of the respondents strongly agreed and $42.7 \%$ agreed that Communication skills improve women participation. Similarly $6.1 \%$ strongly disagree and $8.3 \%$ disagree with the claim. $1.7 \%$ of the respondents' opinions were neutral.

Results show that $43.9 \%$ of the respondents strongly agreed and $47.2 \%$ agreed that Enhanced human resources skills can improve women participation. Similarly $3.3 \%$ strongly disagreed and $4.4 \%$ disagreed with the claim. $1.1 \%$ of the respondents' opinions were neutral.

Results show that $50 \%$ of the respondents strongly agreed and $43.9 \%$ agreed UNWTO made important efforts to improve women participation in tourism development. Similarly $2.2 \%$ strongly disagreed and $2.7 \%$ disagreed with the claim. $1.1 \%$ of the respondents' opinions were neutral.

\section{Discussion of Findings}

The results show that $(56.1 \%)$ of the respondents were female while $(43.9 \%)$ were male. Age distributions with higher percentage are 21-30 years with (28.3\%) and closely followed by $31-40$ years with $25.6 \%$. Those with HND/BSC education certificate have the highest representation (37.8\%) followed by NCE/ OND certificate holder (22.2\%). The Marital status of the respondents $(50 \%)$ were married followed by single with $(46 \%)$ and $4 \%$ Widow/Widower. The occupational distributions showed that majority of the respondents were self-employed with $(18.3 \%)$ while $(16.7 \%)$ of the respondents were working as travel agencies, hoteliers and transporter.

In line with World Tourism Organization (2017), 78\% of the respondents agreed to the fact that tourism is a male dominated sector. Although women do get employed and work as receptionists in hotel industry but results show that $71 \%$ of the respondents agreed that the extent of women participation is low in tourism and transport industry and is relatively insignificant as most are employed in low- skilled sector of the industry such as housekeeping, cleaners and cooking. Furthermore, $89 \%$ of the respondents also testified that the employment status of women in tourism and transport sector is low.

In addition, majority of women interviewed attest that they face many challenges as tourism manager and about $70 \%$ of them do not have capacity to run tourism business and those who owned the tourism business were mainly those who used their personal savings 
and pension to start their business. Many of the younger women did not own businesses due to problems of accessing start-up-capital.

$91 \%$ of the respondents also agreed that collateral to access loans for business growth, poor credit history and inadequate financial capital to purchase proper transport vehicle and office equipment as challenges facing women in tourism industry. Hence, Aina (2016) argued that though males may not be equally affected by financial barriers, the situation is worse for women.

Brown (2016) posited that limited education and training in vocational studies are the barriers affecting women participation in tourism development. In support with Mensual (2018) result indicated that $90 \%$ of respondents stated that in extreme cases, society does not patronize tourism businesses that are run by women due to religion, biological, cultural, attitudinal and societal barriers.

Also childbearing and career development were observed as another factors affecting women participation in tourism development. Furthermore, results show that $92 \%$ of women in transport industry and hotel industry are not adequately engaged and remunerated. They are affected when they are excluded from participation.

Therefore, findings suggest that women should be given opportunity to participate in tourism because they are better at marketing tourism product and hotel facilities in Nigeria. This agreed with Igbojekwe (2013) which revealed that women should be employed due to their efficient and supporting role in services such as reservations, reception, book-keeping and as key in organizing tourist attraction. It was also discovered that the roles of women as travel agents, receptionists, transporter and tour operator is very crucial.

In aggregates, $70 \%$ of the respondents agreed in line with Oduntan (2015) that women should participate in tourism sector, transport and hotel industry because it offers them new employment opportunities. It offers empowerment to women socially and economically. Tourism industry helps women to reduce financial leakage and also serve as source of income generation.

In line with Visser (2018), 87.7\% of the respondents were of the opinion that training and expanding access to loan facilities, internet marketing, formation of business network for self-support as policies to improve women participation. Keethan, (2016) also indicated that education is the fundamental weapon for women to use against discrimination which seem visible in tourism industry. Also $93.9 \%$ of the respondents agreed that poverty eradication programmes must be accompanied by measures to empower women.

Lastly, in aggregate, $83.7 \%$ of the respondents agreed that communication skills, enhanced human resources skills, advocacy campaigns by creating awareness and provision of new tourism employment opportunities could help to tackle low levels of women participation in tourism development as also explained by CEDAW (2014).

\section{Conclusion}

In conclusion, the study revealed that the extent of women participation in tourism, transport and hotel industry is low in Nigeria and is relatively insignificant as most women are employed in low- skilled sector of the industry such as housekeeping and cooking despite male and female employees' equal levels of competence. Furthermore, it is stated in the literature that gender inequality has prevented women from reaching managerial positions in 
their organizations. In Nigeria, it was found that female employees are hired to do semiskilled and hold low-paying jobs due to factors such as lack of financial capital, traditional perception, illiteracy, lack of appropriate education and training, low business capability, cultural factor, racial issues, and religious laws are affecting and relegating women to weak and submissive social roles (Würth, 2014). The restriction of women's opportunities working in the hotel, transport and tourism industry is also prevalent in other countries and not limited to Nigeria.

\section{Recommendations}

In order to ensure that women are effectively rewarded in the tourism sector, the following recommendations will go a long way:

i. The study recommends that there should be training programmes, workshops and seminars financed by Oyo State Government to improve the business skills of women in tourism, hotel and transportation industry;

ii. Policy makers should be more gender-sensitive when drafting the policies for government intervention in tourism development, so that women will have full and appropriate access and right of participation;

iii. Tourism, hotel and transport enterprises should support suitable child care provisions to enable employees (both male and female) remain in their workforce;

iv. Social dialogue between Tourism, hotel and transport enterprises and trade unions should be designed to provide career-entry routes and ladder for matured entrants, careerchangers and women returning to work. 


\section{References}

Adekanye, T.O. (1981). (Adeyokunnu) "Women and Agriculture in Nigeria", United Nation/ECAATRCW/81/11, Addis Ababa, Ethiopia, pg. 15.

Aina, I. O. (2001), "Women, Cultural and Society" in Amadu S. and Adetanwa O. (eds.) Nigerian Women in Society and Development; Ibadan: Dokun Publishing House. Pg.329.

AremuBaines, A. (1998) "Technology and tourism." Work Study 47, (5) 160-163. http://dx.doi.org/10.1108/00438029810370492 Baum, T., Amoah, V., \&Spivack, S. (1997) "Policy dimensions of human resource management in the tourism and hospitality industries." International Journal of Contemporary Hospitality Management 9, (5) 221229. http://dx.doi.org/10.1108/09596119710172615

Biswas, R., \&Cassell, C. (1996) "Strategic HRM and the gendered division of labor in the hotel industry: A case study." Personnel Review 25, (2) 19-34. http://dx.doi.org/10.1108/00483489610147870

Brewster, C., \& Scullion, H. (1997) "A review and an agenda for expatriate HRM." Human Resource Management Journal 7, (3) 32-41. http://dx.doi.org/10.1111/j.17488583.1997.tb00424.x

CEDAW (2003), Special measures to accelerate equality between men and women. Report of Commission on the Elimination of All Forms of Discrimination Against Women. United Nations.Pg 49-50.

Claridge, T, 2004. Designing Social Capital Sensitive Participation Methodologies. Report, Social Capital Research, Breisbane, Australia

Dankelma, I. and Davidson, J. (1997), Women and Environment in the Third World. London. Earth Scan Publications Ltd.

Davies, D., Taylor, R., \&Savery, L. (2001) "The role of appraisal, remuneration and training in improving staff relations in the Western Australian accommodation industry: a comparative study." Journal of European Industrial Training 25, (7) 366-373. http://dx.doi.org/10.1108/EUM0000000005837

Development (2002), Sustainable Development Developments. Issue 18, P.6 DFID (2004), Country Assistance Plan for Nigeria, Department for International Development.

December DFID (2002), Eyes on the future: New Partnership for Africa's Development (NEPAD).

Developments, Issue. 19 DFID (1997), Elimination World Poverty: A Challenge for the 21st Century.

Developments (2004), “Women groups can save babies lives" DFID Developments, Issue 4, P 25- www.ich.ucl.ac.ck/

Fajuyigbe,O, Balogun VF and Obembe, OM (2007)" Web- Based Geographical Information System (GIS) for Tourism in Oyo State, Nigeria, in Information Technology Journal Science Alert volume6 (5):613-622, (2007). https://scialert. Net/ abstract/? Doi=itj.2007.613.622 
Gröschl, S., \& Doherty, L. (1999) "Diversity Management in Practice." International Journal of Contemporary Hospitality Management 11, (6) 262-268. http://dx.doi.org/10.1108/09596119910281757

Hayajenh, A. F., Maghrabi, A. S., \& Al-Dabbagh, T. H. (1994) "Research Note: Assessing the Effect of Nepotism on Human Resource Managers." International Journal of Manpower 15, (1) 60-67. http://dx.doi.org/10.1108/EUM0000000003933

IBM Corporation (2013). IBM SPSS Statistics for Windows, Version 22.0. Armonk, NY: IBM Corp.

Iwu, C.G.; Ezeuduji, I.O.; Eresia-Eke, C. \& Tengeh, R. (2016). The Entrepreneurial Intention of University Student: The Case of a University of Technology in South Africa. Act a Universities Danubius O Economical, Vol. 12, No. 1, pp.164-181.

ILO (2011): Toolkit on Poverty Reduction through Tourism, Geneva, pg. 21

Jorge Ferrer, J.N. Revisioning transpersonal theory: a participatory vision of human spirituality, 2002 SUNNY p225 retrieved 2017.

Krishna Kumari J. (2014): Woman Empowerment through Entrepreneurship in Service Sector with special Reference to SHGs in Tourism, Volume-3, Issue-9, Sept-2014, ISSN No $2277-8160$.

Kattara, H. (2005) "Career challenges for female managers in Egyptian hotels." International Journal of

Lee, C., \& Chon, K.S. (2000) "An investigation of multicultural training practices in the restaurant industry: the training cycle approach." International Journal of Contemporary Hospitality Management 12, (2).http://dx.doi.org/10.1108/09596110010309934

Levy, C. (1986), “The process of Institutionalizing Gender in Politics and Planning: The "WEB" of Institutionalizing" cited in Nigerian Women Society and Development; Ibadan: Dokun Publishing House, pp 18-23.

Li, L., \& Leung, R. W. (2001) "Female managers in Asian hotels: profile and career challenges." International Journal of Contemporary Hospitality Management 13, (4) 189196. http://dx.doi.org/10.1108/09596110110389511

Linehan, M., \& Scullion, H. (2001) "Challenges for female international managers: evidence from Europe." Journal of Managerial Psychology 16, (3) 215-228. http://dx.doi.org/10.1108/02683940110385767

Liu, J. \& Wilson, D. (2001): "The unchanging perception of women as managers." Women in Management Review 16, (4) 163-173. http://dx.doi.org/10.1108/09649420110392145

Magablih, K. (2000) "Role of Female Employees in the Hotel Industry of Jordan." Al Edari $83,181-210$.

Magablih, K. (2006) "Dimensions of Women Participation in the Jordanian Tourism Industry." Abhath Al Yarmouk 22, (1) 95-122.

Masadeh, M. (2009) Human Resources in International Hotel Chains in Jordan: "Out-ofCountry” Training Determinants. Unpublished PhD thesis, Coventry University. 
Maxwell, G. A. (1997) "Hotel general management: views from above the glass ceiling." International Journal of Contemporary Hospitality Management 17, (3) 238-251. http://dx.doi.org/10.1108/09596110510591927

NSCB Tourism Paper, 2004. "What is Tourism"? Retrieved May5, 2006 from: http:// www.africantourism.com/ghana.htm.

National Policy on Environment (NPC) (1998). The Paragraph 2 Formulation by the FEPA shortly after its establishment by Decree No 58 of December 30.

NEEDS (2004), Nigeria: National Economic Empowerment and Development Strategy National Planning Commission, Abuja. Oladeji, S.I. (2006), Reflection on the Issue of Employment and Poverty Reduction in the Context of "NEEDS", Nigeria.

Olumese, I. (2001), Women in Non-Governmental Organization, "In Nigerian Women in Society and Development; Ibadan: Dokun Publishing House pg. 156-159.

Olayinka A.I., Taiwo V.O. Raji A, Oyelade and Farai I (2006) "Importance of Conceptual Framework" in Methodological Basic and Applied Research $2^{\text {nd }}$ Edition pg. 38 published by The Post graduate School University of Ibadan ISBN978-37883-9-6 .http://www.postgraduateschool.ui.edu.ng

Olayinka A.I., Taiwo V.O. Raji A, Oyelade and Farai I (2006) "Distinction Between Theoretical and Conceptual Frameworks " in Methodological Basic and Applied Research $2^{\text {nd }}$ Edition pg. 40 published by The Post graduate School University of Ibadan ISBN978-37883-9-6 .http://www.postgraduateschool.ui.edu.ng

Paper presented at the Consultative Forum on Medium Term Plan for Nigeria (2007-2011) at the Nigeria Institute of Social and Economic Research (NISER) Ibadan, 13-14 March, Pg.6

Peacock, M. (1995) "A job well done": hospitality managers and success." International Journal of Contemporary Hospitality Management 7, (2) 48-51. http://dx.doi.org/10.1108/09596119510079990

Pine, R. (1997) "Hong Kong's Changing Hotel Industry and the Current and Potential Utilization of Women in Management and Leadership Roles" Working Papers, Hong Kong.

Ramos, V., Rey-Maquieira, J., \&Tugores, M. (2004) "The Role of Training in Changing an Economy Specializing in Tourism." International Journal of Manpower 25, (1) 55-72. http://dx.doi.org/10.1108/01437720410524992

Report of the Working Group on Tourism for xii Five Year-Plan, pg. 28

Shirley, S. (1995) "Getting the Gender Issue on the Agenda." Professional Manager, January, 12- 14.

Smith, P.L., \& Smits, S.J. (1994) "The Feminization of Leadership?"Training and Development, February, 43-6 Tikekar, S.R. (2007) Epigrams from Gandhiji. Retrieved from http://www.mkgandhi.org/epigrams/w.htm

Sandhya Rani G. (2013): Recent Trends in Tourism Industry and Women, Volume: 3, Issue: 10 , 
2249555Xhttp://www.academia.edu/9038009/Tourism_as_a_tool_for_Gender_Equality_ and_Women_empowerment_in_India The case for change (2010): Women working in hospitality, leisure, travel and tourism, Executive Summary, November 2010. http://ethics.unwto.org/content/gender-and-tourism.

Tomilayo O, (2004) "Women Definition" in African Women in Agriculture; Published by Centre for Gender, Governance and development (CEGGAD) Ibadan, Nigeria ISBN: 978-32811-6-X, pg. 2.

Timo, N., \& Davidson, M. (2005) "A Survey of Employee Relations Practices and Demographics of MNC Chain and Domestic Luxury Hotels in Australia." Employee Relations 27, (2) 175-192. http://dx.doi.org/10.1108/01425450510572694

Treven, S. (2003) "International Training: The Training of Managers for Assignment Abroad." Education + Training 45, (8/9) 550-557.

Warham, E. (2001), Feeding the World. Developments Issue 13 DFID: Glasgow: UK.

World Tourism Organization (2011): Global Report on Women in Tourism (2010), ISBN: 978-92-844-1373-7 (UNWTO), ISBN: 978-1-936291-36-6 (UN Women), Madrid Spain.

Woods, R.H., \& Vineland, D. (2000) "Women in hotel management." Cornell Hotel and Restaurant

WTTC: Gender equality and youth employment: Travel and Tourism as a key employer of women and young people

WTO (2001).Global Report on Women in Tourism 2010 - World Tourism.Retrieved 25 April 2016, from http://www2.unwto.org/sites/all/files/pdf/folleto_globarl_report.pdf.

White paper on International Development. DFID (2002), Better Livelihoods for Poor People: The Role of Agriculture. Strategies for Achieving the International Development Targets, pg. 6 and 11. 